\title{
Length of stay is associated with incidence of in-hospital malnutrition in a group of low-income Brazilian children
}

Gilberto Kac, M.S.P., (1) Patricia Camacho-Dias, M. en Nutr., (2) Daniele Silva-Coutinho, Lic. en Nutr., ${ }^{(3)}$ Rosana Silveira-Lopes, Lic. en Nutr., ${ }^{(3)}$ Viviane Vilas-Boas A. Marins, Lic. en Nutr., ${ }^{(3)}$ Ana Beatriz V. Pinheiro, Lic. en Nutr. ${ }^{(3)}$

\author{
Kac G, Camacho-Dias P, Silva-Coutinho D, \\ Silveira-Lopes R, Vilas-Boas V, Pinheiro ABV. \\ Length of stay is associated with incidence \\ of in-hospital malnutrition \\ in a group of low-income Brazilian children. \\ Salud Publica Mex 2000;42:407-4 I 2.
}

\begin{abstract}
Objective. To test the hypothesis that increased length of stay and anthropometric status at admission are significant factors associated with in-hospital malnutrition (IHM). Material and methods. Prospective study with two weight (admission and discharge) and one height (admission) measurements per child at the Instituto de Puericultura e Pediatria Martagão Gesteira (IPPMG), Rio de Janeiro, Brazil. The study included 456 children of low socioeconomic status under 10 years of age admitted to the IPPMG during 1997. Statistical analysis involved calculation of in-hospital malnutrition (IHM) prevalence by covariates. The length of hospital stay varied from I to 69 days. Association of IHM with gender, age category, length of stay, presence of wasting, and stunting, was tested by calculating odds ratios using multivariate logistic regression. Results. Logistic regression showed that after adjusting for gender, age category, and presence of stunting at admission, presence of wasting at admission $(\mathrm{OR}=0.07, \mathrm{Cl} 95 \% 0.0 \mathrm{I}-0.55)$ and length of stay from 17 to 69 days $(O R=4.68, \mathrm{Cl} 95 \% 2.00-10.95)$, were statistically associated with IHM in the final model. Conclusions. As intervention measures, the authors suggest implementation of an early identification system for children at risk of developing IHM, along with a review and implementation of in-hospital feeding protocols.
\end{abstract}

Kac G, Camacho-Dias P, Silva-Coutinho D, Silveira-Lopes R, Vilas-Boas V, Pinheiro ABV. El periodo de hospitalización está asociado con la incidencia de desnutrición en un grupo de niños brasileños de bajo nivel socioeconómico. Salud Publica Mex 2000;42:407-4 I 2.

\section{Resumen}

Objetivo.Verificar la hipótesis de que un periodo de hospitalización prolongado y el estado nutricional al ingreso son factores significativamente asociados con la desnutrición durante la hospitalización. Material y métodos. Estudio prospectivo con dos mediciones de peso (al ingreso y al alta) y una medición de estatura (al ingreso) por niño, realizado en el Instituto de Puericultura y Pediatría Martagão Gesteira (IPPMG), Río de Janeiro, Brasil. El estudio incluyó 456 niños de bajo nivel socioeconómico menores de 10 años de edad, admitidos en el IPPMG durante 1997. El análisis estadístico incluyó cálculo de prevalencia de desnutrición intrahospitalaria conforme a covariables. El periodo de hospitalización varió de I a 69 días. El análisis estadístico consistió en el cálculo de razones de momios usando regresión logística multivariada, para probar la asociación entre la desnutrición intrahospitalaria y género, edad, periodo de hospitalización, presencia de emaciación y estatura baja para la edad. Resultados. La regresión logística mostró que después de ajustar por género, edad y estatura baja para la edad al ingreso, la presencia de emaciación al ingreso (OR= $0.07, \mathrm{Cl} 95 \% 0.0 \mathrm{l}-0.55$ ) y el periodo de hospitalización de 17 a 69 días (OR=4.68, Cl 95\% 2.00 - 10.95) resultaron estadísticamente asociados con desnutrición intrahospitalaria en el modelo final. Conclusiones. Como medidas de intervención, los autores sugieren implementar un sistema precoz de identificación al ingreso de los niños

Presented at the IV Congresso Brasileiro de Epidemiologia, Rio de Janeiro, I - 5 of August, 1998.

(I) Departamento de Nutrição Social e Aplicada, Instituto de Nutrição Josué de Castro (INJC), Universidade Federal do Rio de Janeiro (UFRJ), Brasil.

(2) Programa de Pós Graduação em Nutrição Humana, INJC, UFRJ, Brasil.

(3) Setor de Nutrição Clínica, Instituto de Puericultura e Pediatria Martagão Gesteira, UFRJ, Brasil.

Received on: January 3, 2000 - Accepted on: August 22, 2000

Reprint requests to: Dr. Gilberto Kac. Departamento de Nutrição Social.

Av. Brigadeiro Trompowsky S/N ${ }^{\circ}$ - Bloco J - $2^{\circ}$ andar, Rio de Janeiro, RJ. 2194I-590, Brasil.

e-mail: gkac@gbl.com.br 
Key words: anthropometry; nutrition disorders; hospitalization; child; Brazil con riesgo de desarrollar desnutrición intrahospitalaria, junto con una revisión e implementación de protocolos de alimentación hospitalaria.

Palabras clave: antropometría; trastornos nutricionales; hospitalización; niño; Brasil
A nthropometry to monitor nutritional status is con sidered a basic procedure for various public health purposes. ${ }^{1}$

From a clinical perspective, knowledge of the nutritional status of a hospitalized child is an indispensable strategy for establishing an adequate approach to the maintenance and/or recovery of nutritional status during the hospital stay. ${ }^{2-4}$ Jeopardized nutritional status is known to have an important impact on the course of underlying diseases, such as diarrhea and respiratory illness, among others. These patients are thus exposed to a longer stay, which in turn deteriorates their nutritional status., ${ }^{2,5-7}$

No studies focusing on the evolution of nutritional status over the course of hospitalization were identified in Brazil, although some studies on the nutritional status of hospitalized children are available. ${ }^{8-10}$ However, there is a vast international literature on the topic. ${ }^{2,4,7,11-13}$ The development of studies focusing on this topic in Brazil would be important to define more precisely clinical protocols for nutritional management during admission and hospitalization.

An important methodological question is the absence of specific criteria for the definition of in-hospital malnutrition (IHM), thus making direct comparisons difficult across studies. In general, such studies report that hospitalization per se constitutes a major risk factor for IHM and that the greater the length of stay, the higher the probability that the child will develop IHM.

This article presents data on factors potentially associated with the incidence of IHM in a sample of low-income children under 10 years of age, admitted over the course of year 1997 to the Instituto de Puericultura e Pediatria Martagão Gesteira (IPPMG) at the Universidade Federal do Rio de Janeiro (UFRJ), Brazil.

\section{Material and methods}

The study was performed using a database produced by the Clinical Nutrition Service at the IPPMG, a tertiary public health care unit at the Universidade Federal do Rio de Janeiro, Brazil, with information on 753 children ranging from 1 to 144 months of age, hospitalized during the year 1997. Length of stay varied from 1 to 69 days of hospitalization.

Eligibility criteria for this study were defined as age under 10 years, use of anthropometry data only from the first admission in 1997, clinical diagnoses that were not cancer, leukemia, and other chronic disease such as AIDS and renal problems, height-for-age Z-score (HAZ) values from -5 to +3 , weight-for-height (WHZ) from -4 to +5 , and weight-for-age (WAZ) from -5 to +5 . These Z-score ranges were defined according to World Health Organization guidelines ${ }^{1}$ and are considered the biologically plausible ranges. Chronic diseases were eliminated as a tentative to control for the potential association between this type of diseases and greater length of stay and thus greater exposure to IHM. Finally, this age range was selected, since the classic anthropometric indicators (WAZ, HAZ, and WHZ) are appropriate for use with children younger than 10 years. A total of 116 children (15.4\%) were excluded because they did not meet the age criteria, $84(11.2 \%)$ had more than one admission, 52 (6.9\%) had cancer, leukemia, and other chronic disease, and 45 (5.9\%) were excluded because of implausible Z-score values. The final sample included 456 children with complete weight and height data.

Anthropometric data were collected according to standard procedures ${ }^{14}$ by two nutritionists from the Clinical Nutrition Division of the IPPMG, as a routine hospital procedure. For weight data (at admission and discharge), an infant scale was used (Filizola Model 30, Indústrias Filizola S/A, Brazil) for children under 24 months, accurate to 10 grams (in the recumbent position and undressed) and a platform scale (Filizola Model 31, Indústrias Filizola S/A, Brazil) for children over 24 months (standing, with as little clothing as possible), accurate to $0.1 \mathrm{Kg}$. Data on length (for children under 24 months) were obtained using an infantometer made at the hospital, accurate to $0.1 \mathrm{~cm}$. Children over 24 months had their height measured in the orthostatic position using a stadimeter (Filizola Model31, Indústrias Filizola S/A, Brazil), accurate to $0.5 \mathrm{~cm}$.

Assessment of nutritional status at admission was performed using traditional anthropometric indicators 
(weight-for-age, height-for-age, and weight-forheight). Anthropometric indices were calculated using the EPINUT routine from EPI INFO version 6.04, which uses the United States reference from the National Center for Health Statistics ${ }^{15}$ for comparisons. We considered children low height-for-age (stunting), low weight-for-height (wasting), and low weight-for-age (underweight), when they presented Z-score values two standard deviations below the median for the U.S. reference population. ${ }^{15,16}$

Nutritional diagnosis at discharge was performed only on the basis of weight-for-age, since the height measurement was not available. Thus, the change in weight-for-age Z-score was defined as the difference between the Z-scores at admission and at discharge. A drop equal to or greater than 0.5 standard deviation units was defined as in-hospital malnutrition. This cut-off was adopted in the absence of specific criteria from the literature on this topic. Another parameter we used was a weight loss of up to $0.5 \mathrm{Z}$-scores, expected among sick children admitted to the hospital, who are at greater risk of becoming malnourished. Thus, by using this cut-off point we believe that we are not overestimating the incidence of IHM, as would happen if the cut-off were any negative variation in the weight-for-age Z-score difference between admission and discharge.

Data on sex, dates of admission and discharge, and birth, were abstracted from the medical record and incorporated into a database. Length of stay was calculated as the difference, in days, between the date of admission and the date of discharge. This variable was analyzed categorically and divided into the following distribution quartiles: 1-5 days, 6-9 days, 10-16 days, and 17-69 days of hospitalization. The age variable was calculated using the date of birth and the dates of admission and discharge. Thus, for calculating the anthropometric indicators we used two age values, one at admission and the other at discharge.

Statistical analysis included calculation of prevalences for wasting, stunting, and underweight, and means and standard deviations for each of the anthropometric indices at admission. To compare the Z-score means for each indicator by sex we used the Student's $t$ test and analysis of variance (ANOVA) for comparisons of age categories. To compare incidences of IHM by sex, age category $(0-5.9 ; 6-11.9 ; 12$ - 23.9; 24 - 54.9; $60-119.9$ months), and length of stay we used the chisquare test. We also calculated the odds ratio and respective 95\% confidence intervals for IHM for selected variables: sex, length of stay, age, and nutritional status at admission, according to the three anthropometric indicators.
Predictors (independent variables) potentially associated with IHM (dependent variable) were assigned values of 1 and 0 for the exposed and unexposed categories, respectively. The multivariate model was performed based on bivariate associations displaying statistical significance with $p<0.05$. To construct the models and select the best one, we used the logistic regression technique estimating odds ratios with $95 \%$ confidence intervals and adjustment for confounding. ${ }^{17}$ The final model was adjusted for age categories, gender and for the presence of stunting at admission. Weight for age was not included in the final model to avoid colinearity both with weight for height and height for age. All statistical significance analyses used $p<0.05$. All of the procedures were performed with the SPSS/PC+ software, version 8.0.

\section{Results}

Of the 456 children studied, $59 \%$ were males and $41 \%$ females. The age distribution was relatively uniform. Table I presents prevalence data for stunting, wasting, and underweight. Prevalence of malnutrition at admission was $17.1 \%$ for stunting, $10.7 \%$ for wasting, and $20.4 \%$ for underweight. Z-score means were systemat-

Table I

Prevalence of stunting, wasting, ANd UNDERWEIGHT AT ADMISSION (< -2 Z-SCORE), ACCORDING TO GENDER AND AGE CATEGORY, FOR CHILDREN IN A BRAZILIAN HOSPITAL, 1997

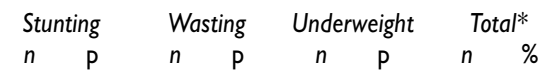

\begin{tabular}{lllllllll}
$\begin{array}{l}\text { Gender } \\
\text { Male }\end{array}$ & 50 & 18.5 & 27 & 10.0 & 55 & 20.4 & 270 & 59.2 \\
\hline Female & 28 & 15.1 & 22 & 11.8 & 38 & 20.4 & 186 & 40.8
\end{tabular}

\begin{tabular}{crrrrrrrr} 
Age (months) & & & & & & & \\
0.0 a 5.9 & 26 & 24.8 & 11 & 10.5 & 32 & 30.5 & 105 & 23.0 \\
\hline 6.0 a 11.9 & 8 & 16.7 & 4 & 8.3 & 13 & 27.1 & 48 & 10.5 \\
\hline 12.0 a 23.9 & 11 & 14.9 & 12 & 16.2 & 17 & 23.0 & 74 & 16.2 \\
\hline 24.0 a 59.9 & 20 & 18.2 & 12 & 10.9 & 20 & 18.2 & 110 & 24.1 \\
\hline 60.0 a 119.9 & 13 & 10.9 & 10 & 8.4 & 11 & 9.2 & 119 & 26.1
\end{tabular}

$\begin{array}{lllllllll}\text { Total } & 78 & 17.1 & 49 & 10.7 & 93 & 20.4 & 456 & 100.0\end{array}$

$\mathrm{n}$ : number of observations

p:prevalence

* relative distribution by gender and age category 
ically negative and consistent with the observed prevalences.

Results for prevalence for each indicator evaluated by sex and age category, demonstrated that the prevalence of stunting was higher among children from 0.0 to 5.9 months of age and lower among children from 60.0 to 119.9 months in both sexes. We also observed that prevalence of low height-for-age among girls tended to decrease with age, which was not observed in boys (analyses not shown). Prevalence of low weightfor-height did not differ statistically among age categories. When the mean Z-scores were compared for the two sexes across age categories, we observed that boys showed slightly higher values than girls, but that the difference was only statistically significant in the 24.0-59.9 month category ( $p=0.051$ ) (analyses not shown). As for weight-for-age, both for the children as a whole $(p=0.008)$ and for boys only $(p=0.012)$, the prevalence decreased with age. When comparing the sexes there was no statistically significant difference between prevalences in any age category.

Data on incidence of IHM by length of stay and sex revealed that the greater the length of stay, the higher the incidence of IHM. Values for boys increased from $9.6 \%$ (1-5 days) to $26.6 \%$ amongst those hospitalized for a longer period (17-69 days). Among girls the incidence reached $33.9 \%$ in the group with the greatest length of stay. These differences were statistically significant both for boys $(p=0.026)$ and girls $(p=0.001)$. As for incidence of IHM in the two sexes, we noted that it was always slightly higher among girls, except for the length of stay category from 1 to 5 days. However, these differences were not statistically significant for any length-of-stay group (results not shown).

Data in Table II include univariate analysis for incidence of IHM, odds ratio, and $95 \%$ confidence intervals for selected variables. We observed that greater length of stay was an important risk factor for IHM, since the OR for developing IHM during hospitalization was 4.20 times higher (CI 95\% 1.82 - 9.69, $p<0.001$ ) for children with greater length of stay (17-69 days). With regard to anthropometric status at admission, children admitted with wasting and underweight were less likely to develop IHM during hospitalization than those not malnourished at admission, with odds ratios of 0.10 (CI 95\% $0.01-0.73, p=0.024)$ and 0.38 (CI $95 \% 0.16-0.86, p=0.020)$, respectively. No association was found between IHM and gender, age, or stunting at admission.

Table III presents the results of logistic regression analysis, using IHM as the dependent variable. We observed that the variables that remained statistically associated with IHM in the model after adjusting for
Table II

Prevalence, odds ratio, confidence interval $\mathbf{9 5 \%}$ OF IN-HOSPITAL MALNUTRITION FOR SELECTED VARIABLES IN A SAMPLE OF BRAZILIAN CHILDREN, 1997

\begin{tabular}{lllll} 
Selected variables & Prevalence & OR & $\mathrm{Cl}(95 \%)$ & P value \\
$\begin{array}{l}\text { Gender } \\
\text { Male }\end{array}$ & 14.4 & & & \\
\hline Female & 17.2 & 0.81 & $(0.48-1.35)$ & 0.420
\end{tabular}

Age category

\begin{tabular}{|c|c|c|}
\hline 0.0 to 5.9 & 15.2 & \\
\hline 6.0 to 11.9 & 16.7 & \\
\hline 12.0 to 23.9 & 24.3 & \\
\hline 24.0 to 59.9 & 14.5 & \\
\hline 60.0 to 119.9 & 10.9 & $0.91 \quad(0.77-1.0,8)$ \\
\hline
\end{tabular}

Lenght of hospitalization

\begin{tabular}{lrrr}
\hline to 5 days* & 9.0 & & \\
\hline 6 to 9 days & 10.5 & & \\
\hline 10 to 16 days & 13.6 & & \\
\hline 17 to 69 days & 29.4 & $4.20(1.82-9.69)$ & 0.000
\end{tabular}

\begin{tabular}{lrlll}
$\begin{array}{l}\text { Underweight at admission } \\
\text { Yes }\end{array}$ & 7.5 & & & \\
\hline No & 17.6 & 0.38 & $(0.16-0.86)$ & 0.020
\end{tabular}

Stunting at admission

\begin{tabular}{lllll} 
Yes & 14.1 & & & \\
\hline No & 15.9 & $0.87(0.43-1.74)$ & 0.690
\end{tabular}

Wasting at admission

\begin{tabular}{lrrrr} 
Yes & 2.0 & & & \\
\hline No & 17.2 & 0.10 & $(0.01-0.73)$ & 0.024
\end{tabular}

* Reference category

Table III

LOGISTIC REGRESSION OF IN-HOSPITAL MALNUTRITION IN CHILDREN IN A BRAZILIAN HOSPITAL, 1997

\begin{tabular}{lccc}
$\begin{array}{l}\text { Independent variables* } \\
\text { Wasting at admission }\end{array}$ & 0.075 & $(0.010-0.566)$ & 0.012 \\
$\begin{array}{l}\text { Lenght of hospitalization } \\
6 \text { to } 9 \text { days }\end{array}$ & 1.167 & $(0.459-2.969)$ & 0.745 \\
\hline 10 to 16 days & 1.560 & $(0.633-3.845)$ & 0.333 \\
\hline I7 to 69 days & 4.682 & $(2.001-10.953)$ & 0.000 \\
& & & \\
* Note: Final model adjusted for age, gender, and presence of stunting at \\
admission
\end{tabular}

confounders (age, gender, and anthropometric status at admission) were: wasting at admission $(\mathrm{OR}=0.075$, CI $95 \% 0.010-0.566, p=0.012)$ and length of stay from 17 to 69 days $(\mathrm{OR}=4.682$, CI $95 \% 2.001-10.953$, 
$p<0.001)$. The variable underweight at admission was not included in the final model, to avoid colinearity with weight for height and height for age. No interaction was observed between the variables sex and age category, and the final model was highly significant $\left(-2\right.$ Log Likelihood $\left.=358.1, \chi^{2}=35.7, \mathrm{df}=4, p<0.001\right)$.

\section{Discussion}

No previous studies were found on incidence of IHM in Brazil. On the other hand, there are numerous studies on the nutritional status of population groups. ${ }^{18-21}$

Anthropometry has been widely used for years to evaluate health and nutritional status. ${ }^{1,16}$ Thus, evaluation of nutritional status at admission constitutes a fundamental strategy for predicting future mortality risks. ${ }^{22}$

Malnutrition is an aggravating factor for mortality in children from 0 to 5 years of age. According to Bern et $\mathrm{al}_{1}{ }^{23}$ malnutrition is associated with 40 to $60 \%$ of deaths in children under 5 years of age in developing countries. According to conventional methods for classifying causes of death, approximately $70 \%$ of deaths in children from 0 to 4 years of age are due to diseases like diarrhea, respiratory infections, malaria, and immune system disorders, and $56 \%$ of these deaths can be attributed to effects potentiated by malnutrition. ${ }^{24}$

As mentioned above, the literature is not explicit as to the adoption of a specific cut-off point for characterizing IHM in children. Thus, the current study adopted weight-for-age Z-score differences greater than 0.5 standard deviation units as IHM. We believe that this definition does not overestimate the observed incidence of IHM. Analyses not shown revealed incidence rates on the order of $60 \%$ when IHM was defined as any negative variation between weight-for-age Z-score at admission and discharge. Such values are extremely high and are certainly not compatible with the overall anthropometric status of this sample of children, despite their low socioeconomic status.

In the absence of indicators to draw the socioeconomic profile of this sample, we relied on the empirical knowledge of the background of users at the Clinic. We know empirically both because of the geographical location (outskirts of a large city) and the fact that it is a public tertiary health care service that the demand comes basically from low-income individuals. Anthropometric indicators at admission were unsatisfactory, in other words, prevalences of wasting, stunting, and underweight observed at admission were higher than those observed for the Brazilian population as a whole, in the last three nationwide nutritional surveys. ${ }^{18,19,21}$
Most of the studies published in Brazil on the nutritional status of hospitalized children are based on the classifications by Gomez and Waterlow and the percentile system, which are no longer recommended because of a number of drawbacks. ${ }^{1}$ This methodological difference makes it difficult to compare the results of such studies with ours. In addition, we found no studies that actually focus on incidence of IHM.

The occurrence of IHM was quite high in this sample, and several factors are known to contribute to it. Dickerson ${ }^{12}$ identifies the following possible causes of IHM: the type of diseases affecting patients, which often interfere with appetite and the patient's ability to handle meals; the appearance or palatability of the meal itself; and the hospital routine, which in some cases interferes with the patient's feeding habits, such as nursing procedures performed around meal times.

Unfortunately we could not determine the dietary intake of children in this study, which would have greatly improved the strength of the investigation. We suggest that future studies along the same line should include dietary analysis.

One would expect that malnourished children would have their nutritional status aggravated while hospitalized, since they are more susceptible to infection due to their debilitated immune state..$^{2,4}$ Using logistic regression, this study indicates that wasting at admission was a protective factor against the occurrence of IHM (OR= 0.07, CI 95\% $0.01-0.56, p=0.012)$. This finding can be explained in part by the fact that children found to be malnourished at admission have little body mass reserves to be depleted, while those admitted in satisfactory nutritional condition have available body mass for catabolism. Another possible argument is that more attention is given to children with a greater nutritional deficit as compared to eutrophic children, who are more prone to being overlooked by the health team. However, these results should be interpreted with caution, since from the public health point of view this situation is neither desirable nor recommendable.

Another factor potentially associated with incidence of IHM observed in the current study was length of stay in the hospital. Results of logistic regression showed that incidence of IHM increased with length of stay. We observed that children hospitalized for longer periods of time (17-69 days) showed an OR for developing IHM of 4.68 (CI 95\%: 2.00 - 10.95) as compared to children who stayed less time in the hospital (1-5 days). This indicates the need, within constraints, of minimizing length of stay in the hospital for these children. Possible explanations for increased incidence of IHM with length of stay involve greater 
exposure to hospital infections and emotional disorders caused by separation from the family environment, which may reduce appetite. ${ }^{12}$

Another hypothesis is that greater length of stay is associated with more serious and complex diseases and consequently greater exposure to IHM. One limitation concerning the current study is the lack of reliable information on admission diagnoses. One can suspect that length of stay could be partially confounded by diagnoses; thus, considering that the type of disease itself may contribute to the incidence of IHM, we eliminated from analysis chronic diseases as leukemia, cancer, AIDS, and renal problems. Based on this procedure we conclude that the above hypothesis is not plausible. Various studies have also shown a worsened or even seriously deteriorated nutritional status with increased length of stay. ${ }^{2-4,7,25}$

The importance of IHM as a public health problem should be recognized in order to implement intervention strategies. ${ }^{26}$ One initial strategy is the formation of a multidisciplinary team with recognized expertise on the issue, allowing for the provision of adequate nutritional support for hospitalized children. ${ }^{4}$ A second strategy consists of implementing an efficient system for identifying all children at risk of IHM at admission, including their characteristics (sex, age, and socioeconomic conditions), ${ }^{2,3,6}$ thereby facilitating the implementation of intervention strategies such as adequate preparation and serving of meals. A firm policy to deal with the problem of IHM is thus indispensable to reduce hospital mortality rates, length of stay, financial costs, and above all the occurrence of the problem itself.

In short, we conclude by underscoring the scarcity of available studies on IHM. The few existing studies focus on nutritional status at admission and fail to evaluate incidence of IHM. Finally, IHM deserves greater attention from health care professionals and researchers, not only because of its financial and health impact, but also to foster a better understanding of its causes, since numerous factors like the underlying disease, quality of hospital care, and even the absence of a specific policy to deal with the problem, can contribute to worsen nutritional status during hospitalization.

\section{References}

I.World Health Organization. Physical status: The use and interpretation of anthropometry. Ginebra:World Health Organization, 1995;WHOTechnical Report Series 854.

2. Allison SP.The management of malnutrition in hospital. Proc Nutr Soc 1996;5:862-865.

3. Gallagher-Allred CR, Voss AC, Finn SC, McCamish MA. Malnutrition and clinical outcomes:The case of medical nutrition therapy. J Am Diet Assoc 1996;96:361-366.
4. Arrowsmith H. Malnutrition in hospital: Detection and consequences. Br J Nurs 1997;6: I |31- | I35.

5.Atalah ES, Bustos PM, Gómez EA. Desnutrición infantil: costo social por patología respiratoria y digestiva. Arch Latinoam Nutr 1983;33:395-408. 6. Nagel MR. Nutritional screening: Identifying patients at risk for malnutrition. Nutr Clin Pract 1994;8: I7I-I75.

7. Chima CS, Barco K, Dewitt ML, Maeda M, Teran JC, Muller KD. Relationship of nutritional status to length of stay, hospital costs, and discharge status of patients hospitalized in the medicine services. J Am Diet Assoc 1997; $97: 975-978$

8. Moura EFA. Estado nutricional de crianças hospitalizadas. Jornal de Pediatria 1990;66:243-246.

9. Leite HP, Isatugo MKI, Sawaki L, Fisberg GM. Anthropometric nutritional assessment of critically ill hospitalized children. Rev Paul Med 1993; I I: 309-3I3.

10. Do Carmo-Leal M, Gama SGN, Vasconcelos AGG. Risk factors for hospitalization and death from diarrhea in a public pediatric hospital in Rio de Janeiro, Brazil. Salud Publica Mex 1996;38:29-36.

I I. Gamatie Y, Prual A, Wollo J, Huguet D. Are pediatric wards in developing countries only places to die? A study of prior to hospitalization risk factors of death among 0-2 year old hospitalized children in Niamey, capital of Niger. J Trop Pediatr 1994;40:54-57.

12. Dickerson J.The problem of hospital-induced malnutrition. Nurs Times 1995;91:44-45.

13. Peterson KE, Wiecha JL, Casey V, Meyers A, Roos N, Frank DA.Assessing unmet need for services for pediatric undernutrition. Am J Prev Med 1995; I I Suppl I:S39-S44.

14. Lohman TG, Roche AF, Martorell R. Anthropometric standardization reference manual. Champaign, Illinois: Human Kinetics, 1988.

15. National Center for Health Statistics. NCHS growth curves for children, birth-18 years. Washington, D.C., Department of Health, Education, and Welfare, 1978;Publication No. (PHS) 78-1650.

16. WHO Working Group. Use and interpretation of anthropometric indicators of nutritional status. Bull World Health Organ 1986;64: 929-941. 17. Kleinbaum DG. Logistic regression:A Self-explanatory Text. Nueva York: Springer-Verlag, 1994.

18. INAN - Instituto Nacional de Alimentação e Nutrição. Perfil de Crescimento da População Brasileira de 0 a 25 anos. Brasília: INAN/IBGE, 1989. 19. Monteiro CA, Benicio MHD, lunes RF, Gouveia NC, Cardoso MAA. Evolução da desnutrição infantil. In Velhos e Novos Males da Saúde no Brasil. A evolução do país e de suas doenças. São Paulo: CA Monteiro, 1995; HUCITEC/NUPENS/USP:93-I I 4.

20. Post CLA, Victora CG, Horta B, Guimarães PR. Desnutrição e obesidade em duas coortes de base populacional no sul do Brasil:Tendências e diferenciais. Cad Saúde Pública 1996; 12 Suppl. I:S49-S57.

21. Sociedade Civil Bem-Estar Familiar no Brasil. Pesquisa Nacional sobre Saúde e Demografia. Brasília: Litografia Tucano Ltda, 1997.

22. Prudhon C, Golden MH, Briend A, Mary JY. A model for standardised mortality of severely malnourished children using nutritional status on admission to therapeutic feeding centres. Eur J Clin Nutr 1997;5 I: 77I-777.

23. Bern C, Zucker JR, Perkins BA, Otieno J, Oloo AJ,Yip R.Assessment of potential indicators for protein-energy malnutrition in the algorithm for integrated management of childhood illness. Bull World Health Organ 1997;75 Suppl. I:S87-S96.

24. Pelletier DL, Frongillo EA, Schroeder DG, Habicht JP. The effects of malnutrition and child mortality in developing countries. BullWorld Health Organ 1995;73:443-448.

25. Merritt RJ, Suskind RM. Nutritional survey of hospitalized pediatric patients. Am J Clin Nutr 1979;32:1320-1325.

26. McWhirter JP, Pennigton CR. Incidence and recognition of malnutrition in hospital. BMJ 1994;308:945-948. 